\title{
PENGARUH STRES KERJA TERHADAP KINERJA KARYAWAN PADA PT. PLN (PERSERO) AREA BINTARO TANGSEL
}

\author{
Endang Sugiarti \\ email:
}

\begin{abstract}
ABSTRAK
Adapun tujuan dari penelitian ini adalah untuk mengetahui Stress kerja karyawan pada PT. PLN (persero) Area Bintaro, untuk mengetahui Kinerja karyawan pada PT. PLN (Persero) Area Bintaro dan untuk mengetahui Pengaruh Stres Kerja Terhadap Kinerja pada PT. PLN (Persero) Area Bintaro Tangsel.

Penelitian ini menggunakan metode deskriptif kuantitatif, teknik pengumpulan data dengan studi kepustakaan dan studi lapangan, seperti: wawancara, observasi dan kuisioner. Populasi dalam penelitian ini adalah seluruh karyawan PT. PLN (Persero) Area Bintaro yang berjumlah 97 orang/responden. Sampel dalam penelitian ini berjumlah 97 orang/responden. Data yang diperoleh dari penyebaran kuisioner kemudian dianalisis yaitu uji validitas, uji reliabilitas, Regresi Sederhana,uji korelasi product moment, koefisien determinasi dan uji hipotesis.

Dari hasil analisa diperoleh koefisien korelasi product moment diperoleh sebesar 0,509 artinya memiliki pengaruh cukup kuat.Dari hasil perhitungan dengan menggunakan koefisien determinasi hasilnya adalah 56,85\% hal ini berarti kinerja pegawai dipengaruhi oleh Stres Kerja sebesar 24,8\% sedangkan sisanya sebesar 75,2\% dipengaruhi oleh factor lainnyaSelain Disiplin seperti Kepemimpinan,Lingkungan kerja.Penelitian ini menunjukkan adanya pengaruh yang positif dan signifikan antara Stres Kerja terhadap kinerja karyawan Berdasarkan hasil yang menunjukkan $t_{\text {hitung }}>t_{\text {tabel }} y$ aitut ${ }_{\text {hitung }}(5,606)>t_{\text {tabel }}(1,987)$ yang artinya bahwa Ho ditolak dan Ha diterima, artinya Sters Kerja (X) mempunyai pengaruh yang Positif dan signifikan terhadap kinerja karyawan (Y).
\end{abstract}

\section{Kata Kunci: Stres Kerja dan Kinerja Karyawan}

\begin{abstract}
The purpose of this research is to know the employee Stress at PT. PLN (Persero) Bintaro Area, to know the performance of employees at PT. PLN (Persero) Bintaro Area and to know the Influence of Work Stress on Performance at PT. PLN (Persero) Bintaro Tangsel Area.

This research uses quantitative descriptive method, data collection technique with library study and field study, such as: interview, observation and questionnaire. Population in this research is all employees of PT. PLN (Persero) Area Bintaro which amounted to 97 people / respondents. The sample in this study amounted to 97 people / respondents. Data obtained from the questionnaire distribution then analyzed the validity test, reliability test, Regression Simple, product moment correlation test, coefficient of determination and hypothesis test.

From the analysis results obtained product moment correlation coefficient obtained by 0.509 means have a strong enough influence. From result of calculation by using coefficient determination result is $56,85 \%$ this matter mean employee performance influenced by Work Stress equal to 24,8\% while the rest equal to 75,2\% influenced by other factors Besides Discipline like Leadership, Work environment. between Working Stress on employee performance Based on the results show thitung> ttable ie tcount $(5,606)>$ ttabel $(1,987)$ which means that Ho is rejected and Ha accepted, meaningSters Work $(\mathrm{X})$ has a positive and significant impact on employee performance (Y).
\end{abstract}

\section{Keywords: Job Stress and Employee Performance}




\section{PENDAHULUAN}

\section{A. Latar Belakang Penelitian}

Pembangunan dibidang sumber daya manusia yang produktif merupakan salah satu kunci untuk mencapai keberhasilan. Begitu pula dalam perusahaan yang pada dasarnya didirikan dengan tujuan untuk memperoleh laba guna mempertahankan hidup dan perkembangan usahanya. Untuk mencapai tujuan tersebut perusahaan dapat memanfaatkan segala kemampuan dan kesempatan yang ada semaksimal mungkin serta memperkecil hambatan-hambatan dan kelemahankelemahan yang dihadapinya. Dalam mencapi tujuan perusahaan tersebut peranan tenaga kerja tidak dapat disangkal lagi sebagai penentu keberhasilan.

Manajemen Sumber Daya Manusia pada dasarnya menganggap bahwa karyawan adalah kekayaan (asset) utama organisasi yang harus dikelola dengan baik.Keberadaan manajemen sumber daya manusia sangat penting bagi perusahaan/lembaga dalam mengelola, mengatur, mengurus dan menggunakan sumber daya manusia sehingga dapat berfungsi secara produktif, efektif dan efisien untuk tercapainya tujuan organisasi.

Sumber daya manusia memegang peranan penting dalam setiap penyelenggaraan kegiatan perusahaan meskipun peran dan fungsi dari tenaga kerja telah banyak digantikan dengan mesin-mesin industri. Tetapi pada kenyataannya sampai saat ini tenaga kerja masih menjadi faktor yang penting dalam menentukan jalannya proses produksi. Maka dari itu setiap perusahaan menghendaki agar setiap tenaga kerja dapat bekerja secara efektif dan efisien.

Dengan adanya sumber daya manusia tenaga kerja mempunyai peranan penting dalam organisasi karena didalam sumber daya manusia mempunyai peran yang sangat strategis sebagai pelaksana dari fungsi-fungsi manajemen yaitu perencanaan, pengorganisasian, staffing, kepemimpinan, pengendalian, pengawasan, dan pelaksanaan operasional organisasi.Tersedianya sumber daya manusia juga bukanlah jaminan bahwa organisasi tersebut dapat dikelola dengan baik.Untuk itu diperlukan tenaga kerja yang terampil dan professional, sehingga dapat memberikan kontribusi dan kinerja yang optimal sesuai dengan tujuan yang telah ditetapkan oleh organisasi tersebut.

Persaingan dan tuntutan profesionalitas yang semakin tinggi menimbulkan banyaknya tekanan-tekanan yang harus dihadapi oleh karyawan didalam lingkungan pekerjaan maupun diluar lingkungan pekerjaan yang mengakibatkan karyawan terkena stress yang akan menimbulkan pengaruh terhadap kinerja karyawan.

Berdasarkan penelitian terdahulu Harmita (2011:138) hasil penelitian menunjukkan bahwa faktor stress kerja sangat mempengaruhi kinerja karyawan sebesar $40,2 \%$.

Kinerja karyawan merupakan salah satu dimensi yang dapat digunakan untuk mengukur, mengevaluasi kekuatan karyawan dalam bertahan serta melaksanakan tugas dan kewajibannya terhadap organisasi dimana ia bernaung. Para karyawan dituntut untuk dapat melaksanakan tugas yang dibebankannya dengan baik, yait mengoptimalkan waktu bekerja, dan jujur agar dapat mencapai hasil kerja dengan kuantitas dan kualitas yang tinggi.

Irham Fahmi (2010:2), menyatakan bahwa kinerja adalah hasil yang diperoleh oleh suatu organisasi baik organisasi tersebut bersifat profit oriented dan non profit oriented yang dihasilkan selama satu periode waktu.

Anwar Prabu (2008:157), menyatakan bahwa stres kerja adalah peraaan tertekan yang dialami karyawan 
dalam menghadapi pekerjaan. Stress kerja ini tampak dari emosi yang tidak stabil, perasaan tidak tenang, suka menyendiri, cemas, tegang, gugup. Penyebab stress kerja antara lain beban kerja yang dirasakan terlalu berat, waktu kerja yang terlalu mendesak, kuantitas pengawasan yang rendah, iklim kerja yang tidak sehat, ototritas kerja yang tidak memadai yang berhubungan dengan tanggung jawab, konflik kerja, perbedaan nilai antara karyawan dengan pimpinan yang frustasi dalam kerja.

Stress kerja merupakan aspek yang penting bagi perusahaan terutama keterkaitannya dengan kinerja karyawan. Perusahaan harus memilki kinerja, kinerja yang baik dan tinggi dapat membantu perusahaan memperoleh keuntungan. Sebaliknya, bila kinerja menurun dapat merugikan perusahaan. Oleh karenanya kinerja karyawan perlu memperoleh perhatian antara lain dengan melaksakan kajian berkaitan dengan variabel stress kerja.

\section{B. Tujuan dan Manfaat Penelitian}

1. Tujuan Penelitian

Penelitian ini bertujuan antara lain:

a. Untuk mengetahui tingkat stress kerja pada PT.PLN (Persero) Area Bintaro.

b. Untuk mengetahui kinerja karyawan pada PT.PLN (Persero) Area Bintaro.

c. Untuk mengetahui pengaruh stress kerja terhadap kinerja karyawan pada PT.PLN (Persero) Area Bintaro.

2. Manfaat Penelitian

a. Bagi Penulis

Sebagai bahan informasi bagi peneliti yang ingin mengembangkan stress kerja dan kinerja karyawan lebih lanjut, dan sebagai syarat untuk memenuhi gelar strata satu
Ekonomi Manajemen di Universitas Pamulang.

b. Bagi Perguruan Tinggi

Melalui penelitian ini diharapkan dapat memberikan informasi terhadap perkembangan ilmu pengetahuan khususnya dalam ilmu Manajmen Sumber Daya Manusia (MSDM).

c. Bagi Perusahaan

Hasil penelitian dapat bermanfaat sebagai bahan pertimbangan untuk melaksanakan program perusahaan, khususnya yang terkait dengan masalah stress kerja dan kinerja pada PT.PLN (Persero) Area Bintaro.

\section{TINJAUAN PUSTAKA}

\section{A. Manajemen}

\section{Pengertian Manajemen}

Kata manajemen berasal dari bahasa inggris, management yang dikembangkan dari kata to manage, yang artinya mengatur atau mengelola. Kata manage itu sendiri berasal dari bahasa Italia, maneggio, yang diadopsi dari bahasa latin managiare,yang berasal dari kata manus,yang artinya tangan. Pengertian manajemen menurut:

Manajemen menurut Malayu S.P Hasibuan (2008:1) adalah ilmu dan seni mengatur proses pemanfaatan sumber daya manusia dan sumber-sumber lainnya secara efektif dan efesien untuk mencapai suatau tujuan tertentu.

Manajemen menurut Sondang P. siagian (2011:17) adalah kemampuan dan keterampilan untuk memperoleh untuk memperoleh suatu hasil dalam pencapaian tujuan melalui kegiatankegiatan orang lain.

Manajemen menurut G.R Terry (2014:7)merupakan proses perencanaan, pengorganisasian, penggerakan, dan pengendalian atau pengawasan yang dilakukan untuk mencapai sasaran yang 
telah ditentukan melalui pemanfaatan sumber daya manusia dan sumber daya lainnya.

Manajemen menurut Robbin dan Coulter (2012:17) adalah proses pengkoordinasian kegiatan-kegiatan pekerjaan sehingga pekerjaan tersebut terrealisasikan secara efisien dan efektif dengan melalui orang lain.

Berdasarkan pengertian diatas peneliti menyimpulkan manajemen adalah suatu proses yang terdiri dari rangkaian kegiatan seperti perencanaan, pengorganisasian, penggerakan, dan pengendalian/ pengawasan, yang dilakukan untuk menentukan dan mencapai tujuan yang telah ditetapkan melalui pemanfaatan sumber daya manusia.

\section{Dasar-dasar Manajemen}

Dasar-dasar manajemen menurut Malayu S.P Hasibuan (2010:2) sebagai berikut:

a. Adanya kerja manajemen diantara sekelompok orang dalam ikatan formal.

b. Adanya tujuan bersama serta kepentingan yang sama yang akan dicapai.

c. Adanya pembagian kerja, tugas, dan tanggung jawab yang teratur.

d. Adanya hubungan formal dan ikatan tata tertib yang baik.

e. Adanya sekelompok orang dan pekerjaan yang akan dikerjakan.

f. Adanya human organization.

\section{Fungsi Manajemen}

Fungsi manajemen dalam organisasi merupakan sebuah perangkat yang penting dan suatu hal yang harus dikembangkan demi tercapainya tujuan organisasi serta memberikan kepuasan pada anggota-anggota didalamnya. Bahkan fungsi manajemen menjadi patokan organisasi dalam mencapai tujuan sehingga setiap aktivitas organisasi harus berlandasakan prosedur
(SOP), strategi, kebijakan dan aturan yang telah dutetapkan dalam fungsi manajemen (POAC). Tujuan dari fungsi manajemen secara umum untuk mengendalikan semua aktivitas organisasi dengan baik, sebagai pengembangan kemampuan SDM yang professional, menghasilkan kinerja yang unggul dan hasil kerja yang maksimal serta tercapainya tujuan yang memberikan kesejahteraan bagi semua pihak yang ada dalam organisasi.

Menurut T. Hani Handoko (2009:23) ada lima (5) fungsi manajemen yaitu:

a. Perencanaan

Rencana-rencana dibutuhkan untuk memeberikan kepada organisasi tujuan-tujuannya dan menetapkan prosedur terbaik untuk pencapaiannya tujuan itu. disamping itu, rencana memungkinkan:

1) Organisasi bisa memperoleh dan mengikat sumber daya yang diperlukan utuk mencapai tujuan-tujuan tertentu.

2) Para anggota organisasi untuk melakukan kegiatan-kegiatan yang konsisten dengan berbagai tujuan dan proseur terpilih, dan

3) Kemajuan terus dapat memonitor dan diukur, sehingga tindakan korektif dapat diambil bila tingkat kemajuan tidak memuaskan.

Perencanaan (palnning) adalah 1) pemilihan atau penetapan Tujuan tujuan organisasi. 2) penentu strategi, kebijaksanaan, proyek, program, prosedur, metode, sistem dan standar yang dibutuhkan banyak terlibat dalam fungsi ini.

b. Pengorganisasian

Setelah para manajer menetapkan tujuan-tujuan dan menyusun rencana-rencana atau program- 
program untuk mencapainya, maka mereka perlu merencang dan mengembangkan suatu organisasian yang akan dapat melaksanakan berbagai program tersebut secara sukses.

Pengorganisasian (organizing) adalah a) penentuan sumber daya dan kegiatan-kegiatan yang dibutuhkan untuk mencapai tujuan organisasi, b) perencanaan dan pengembangan suatu organisasi atau kelompok kerja yang akan dapat "membawa" hal-hal tersebut membawa kearah tujuan, c) penugasan tanggung jawab tertentu dan kemudian, d) pendelegasian wewenang yang diperlukan kepada individu-individu untuk melaksanakan tugas-tugasnya.

c. Penyusunan personalia

Penyusunan personalia (staffing) adalah penarikan (recruitment), latihan dan pengembangan, serta penempatan dan pemberian orientasi para karyawan dalam lingkungan kerja yang menguntungkan dan produktif. Dalam pelaksanaan fungsi ini manajemen menentukan persyaratan-persyaratan mental, fisik, dan emosional untuk posisiposisi jabatan yang ada melalui analisa jabatan, deskripsi jabatan dan spesifikasi jabatan dan kemudian menarik karyawan yang diperukan dengan karakteristikkarakteristik personalia tertentu seperti keahlian, pendidikan, umur, dan pengalaman.

Fungsi ini mencakup kegiatankegiatan seperti pembuatan sistem pengkajian untuk pelaksanaan kerja yang efektif. Penilaian karyawan untuk promosi dan pemecatan serta latihan-latihan dan pengembangan karyawan.

d. Pengarahan
Sesudah rencana dibuat, organisasi dibentuk dan disusun personalia, langkah berikutnya adalah menugaskan karyawan untuk bergerak (leading), secara sederhana, adalah untuk membuat atau mendapatkan para karyawan yang melakukan apa yag diinginkan, dan harus mereka lakukan.

Funsi ini melibatkan kualitas, gaya, dan kekuasaan pemimpin serta kegiatan-kegiatan kepimpinan seperti komunikasi, motivasi dan disiplin. Fungsi leading sering disebut dengan bermacam-macam nama, seperti: leading, directing, motivating, actuating.

e. Pengawasan

Pengawasan (controlling) adalah penemuan dan penerapan cara untuk menjamin bahwa rencana telah dilaksanakan sesuai dengan yang telah ditetapkan. Hal ini dapat positif maupun negative. Pengawasan positif mencoba untuk mengetahui apakah tujuan organisasi dicapai dengan efisien dan efektif. Pengawasan negative mencoba untuk menjamin bahwa kegiatan yang diinginkan atau dibutuhkan tidak terjadi atau terjadi kembali.

Fungsi pengawasan pada dasarnya mencakup empat unsur yaitu: a) penetapan standar pelaksanaan, b) penetuan pelaksanaan, ukuran-ukuran pelaksanaan nyata dan membandingkan dengan standar yang telah ditetapkan, dan d) pengambilan tindakan koreksi yang diperlukan bila pelaksanaan menyimpang dari standar.

\section{B. Manajemen Sumber Daya Manusia} 1. Pengertian Manajemen Sumber Daya Manusia 
Manajemen Sumber Daya Manusia pada dasarnya menganggap bahwa karyawan adalah kekayaan (asset) utama organisasi yang harus dikelola dengan baik. Keberadaan manajemen sumber daya manusia sangat penting bagi perusahaan/lembaga dalam mengelola, mengatur, mengurus dan menggunakan sumber daya manusia sehingga dapat berfungsi secara produktif, efektif dan efisien untuk tercapainya tujuan organisasi.

Manajemen Sumber Daya Manusia dapat didefinisikan pula sebagai suatu pengolahan dan pendayagunaan sumber daya yang ada pada individu (karyawan). Pengolahan dan pendayagunaan tersebut dikembangkan secara maksimal didalam dunia kerja untuk mencapai tujuan organisasi dan pengembangan individu karyawan.

Manajemen Sumber Daya Manusia menurut Malayu S.P Hasibuan (2010:10) adalah "seni mengatur hubungan dan peranan tenaga kerja agar efektif dan efesien membantu terwujudnya tujuan perusahaan, karyawan, dan masyarakat".

Manajemen Sumber Daya Manusia menurut Anwar Prabu Mangkunegara (2012:2) merupakan suatu perencanaan, pengorganisasian, pengkoordinasian, pelaksanaan dan pengawasan terhadap pengadaan, pemberian balas jasa, pengintegrasian, pemeliharaan tenaga kerja dalam rangka mencapai tujuan organisasian.

Manajemen Sumber Daya Manusia menurut Edwin B. Flippo (2009:5) adalah "perencanaan, pengkoorganisasian, pengorganisasian, pengarahan, dan pengawasan kegiatankegiatan, pengadaan, pengembangan, pemberian kompensasi, pengintegrasian, pemeliharaan, dan pelepasan sumber daya manusia agar tercapai berbagai tujuan individu, organisasi dan masyarakat".

2. Fungsi Manajemen Sumber Daya Manusia

Menurut Hasibuan (2008:21) fungsi manajemen sumber daya manusia terdiri dari perencanaan, pengorganisasian, pengarahan, pengendalian, pengadaan, pengembangan kompensasi, pengintegrasian, pemeliharaan, kedisiplinan, dan pemberhentian.

a. Perncanaan

Perencanaan SDM (Human

Resources Planning) adalah perencanaan tenaga kerja secara efektif serta efisien agar sesuai dengan kebutuhan perusahaan dalam membantu terwujudnya tujuan.

b. Pengorganisasian

Pengorganisasian adalah kegiatan untuk mengorganisasi semua karyawan dengan menetapkan kerja, hubungan kerja, delegasi wewenang, integrasi dan koordinasi dalam bagan organisasi (organization chart). Organisasi hanya merupakan alat untuk mencapai suatu tujuan, dengan organisasi yang baik akan membantu terwujudnya tujuan secara efektif.

c. Pengarahan

Pengarahan (directing) adalah kegiatan mengarahkan semua karyawan, agar mau bekerja sama dan bekerja efektif dan efesien dalam membantu tercapainya tujuan perusahaan, karyawan dan masyarakat. Pengarahan dilakukan pimpinan dengan cara menugaskan bawahan agak mengerjakan semua tugasnya dengan baik.

d. Pengendalian

Pengendalian (controlling) adalah kegiatan pengendalian semua 
karyawan agar menaati peraturanperaturan perusahaan dan bekerja sesuai dengan rencana. Apabila terdapat penyimpangan atau kesalahan maka akan diadakan tindakan perbaikan dan penyempurnaan rencana. Pengendalian karyawan meliputi seperti kehadiran, kedisiplinan, perilaku, kerjasama, pelaksanaan pekerjaan dan menjaga situasi lingkungan pekerjaan.

e. Pengadaan

Pengadaan (procurement) adalah proses penarikan karyawan, seleksi, penempatan untuk mendapatkan karyawan yang sesuai dengan kebutuhan perusahaan. Pengadaan yang baik akan membantu terwujudnya tujuan organisasi.

f. Pengembangan

Pengembangan (development) adalah proses peningkatan keterampilan teknis, teoritis, konseptual, dan moral karyawan melalui pendidikan dan pelatihan.

g. Kompensasi

Kompensasi (compensation) adalah pemberian balas jasa langsung (direct) dan tidak langsung (indirect), uang atau barang kepada karyawan sebagai imbalan jasa yang diberikan kepada perusahaan. Prinsip kompensasi adalah adil atau tidak layak. Adil diartikan sesuai dengan prestasi kerjanya, layak diartikan dapat memenuhi kebutuhan primernya serta berpedoman pada batas upah minimum pemerintah.

h. Pengintegrasian

Pengintegrasian (integration) adalah kegiatan untuk mempersatukan kepentingan perusahaan dan kebutuhan karyawan, agar tercipta kerja sama yang serasi dan dan saling menguntungkan.
Pengintegrasian merupakan hal yang peling penting dan sulit dalam manajemen sumber daya manusia, karena mempersatukan dua kepentingan yang bertolak belakang.

i. Pemeliharaan

Pemeliharaan (maintenance) adalah kegiatan untuk memelihara atau meningkatkan kondisi fisik, mental, dan loyalitas karyawan, agar mereka tetap mau bekerja sama sampai pensiun. Pemeliharaan yang baik dilakukan dengan program kesejahteraan yang berdasarkan kebutuhan sebagai besar karyawan serta berpedoman kepada internal dan eksternal kosistensi.

j. Kedisiplinan

Kedisiplinan merupakan fungsi manajemen sumber daya manusia yang terpenting dan kunci terwujudnya tujuan karena tanpa disiplin yang baik sulit terwujud tujuan yang maksimal.

k. Pemberhentian

Pemberhentian (separation) adalah putusnya hubungan kerja seseorang dari suatu perusahaan. Pemberhentian ini disebabkan oleh keinginan karyawan, keinginan perusahaan, kontak kerja berakhir, pensiun, dan sebab-sebab lainnya.

\section{Peranan Manajemen Sumber Daya Manusia}

Manajemen merupakan fungsi yang berhubungan dengan upaya mewujudkan hasil tertentu kegiatan orang lain. Hal ini berarti bahwa sumber daya manusia memiliki peran yang sangat penting bagi dan dominan dalam manajemen.

Menurut I Komang Ardana (2012:6) peranan sumber daya manusia dapat dibedakan menjadi tiga, yaitu sebagai berikut:

a. SDM pengemban misi perusahaan 
Semua perusahaan pasti memilki visi dan misi, sasaran dan tujuan. Visi dan misi tidak akan tercapai tanpa diemban oleh SDM, masalahnya terletak pada kemampuan SDM untuk mengemban misi tersebut dengan baik, untuk itu perlu SDM memiliki keunggulan dan kesungguhan dalam bekerjasama mencapai tujuan organisasi.

b. SDM sebagai pimpinan/manajer perusahaan

Pimpinan/manajer dalam perusahaan terbagi atas tiga tingkatan, yakni pimpinan puncak, pimpinan menengah, dan pimpinan tingkat bawah. Peranan pimpinan sangat penting dalam mencapai keberhasilan perusahaan, karena pimpinan yang menentukan dan memegang kunci dalam pengambilan keputusan setiap kebijakan perusahaan. Dalam menjalankan perannya, setiap pimpinan melakukan banyak kegiatan yaitu membantu prencanaan, memberikan perintah/petunjuk, mengawasi pelaksanaan pekerjaan, menilai hasil kerja dan memberikan nasehat kepada pekerja.

c. SDM sebagai pekerja

Peranan pekerja dalam perusahaan demikian penting sehingga semua unsur yang ada didalamnya akan berfungsi tanpa manusia. Seorang pekerja mengiginkan hasil kerjanya mempunyai nilai dan sepapan dengan kedudukannya dalam perusahaan, semakin tinggi kedudukan seseorang, semakin besar peran yang dimainkan. Karena tertarik akan dapat berperan dalam salah satu bidang pekerjaan, manusia mau bekerja sehingga peran itu dapat dinilai sebagai salah satu motivasi. Peranan seorang pekerja dalam perusahaan dapat bermanfaat secara optimal apabila memiliki kemampuan dan diberikan kesempatan.

III. HASIL PENELITIAN DAN PEMBAHASAN

A. Pengaruh Stres Kerja Terhadap Kinerja Karyawan Pada PT.PLN (Persero) Area Bintaro

\section{Regresi Sederhana}

Dalam menganalisa pengaruh stress kerja terhadap kinerja karyawan pada PT.PLN (Persero) Area Bintaro dari hasil penelitian dan penyebaran kuesioner, untuk mengetahui seberapa besar pengaruh antara stress kerja terhadap kinerja karyawan, maka perlu dilakukan uji koefisien korelasi dengan menggunakan rumus product moment.

\section{B. Uji Koefisien Determinasi}

Selanjutnya untuk mengetahui seberapa besar prosentase pengaruh stress kerja terhadap kinerja karyawan, maka digunakan dilakukan uji koefisien determinasi dengan rumus sebagai berikut:

Keterangan:

KD : Koefisien Determinasi

$\mathrm{r}^{2} \quad$ : Koefisien Korelasi X dan Y

$\mathrm{KD}=\mathrm{r}^{2} \times 100 \%$

$\mathrm{KD}=(0,498)^{2} \times 100 \%$

$\mathrm{KD}=0,248 \times 100 \%$

$\mathrm{KD}=24,8 \%$

Hal ini membuktikan bahwa hasil perhitungan koefisien determinasi adalah $24,8 \%$ artinya adanya kontribusi antara stress kerja terhadap kinerja karyawan sebesar 24,8\% sedangkan selebihnya sebesar $75,2 \%$ dipengaruhi oleh faktor lain.

$$
\begin{aligned}
& \text { 2. Regresi Linier Sederhana } \\
& \mathrm{n}=97 \\
& \sum \mathrm{x}=4037 \\
& \sum \mathrm{y}=3984
\end{aligned}
$$




$$
\begin{aligned}
& \sum x^{2}=169367 \\
& \sum y^{2}=165050 \\
& \sum x y=166497
\end{aligned}
$$

Menghitung rumus b

$$
\begin{aligned}
b & =\frac{n \cdot \sum x y-\left(\sum x\right)\left(\sum y\right)}{n \cdot \sum x^{2}-\left(\sum x\right)^{2}} \\
b & =\frac{97 \cdot 166497-(4037)(3984)}{97 \cdot 169367-(4037)^{2}} \\
b & =\frac{16150209-16083408}{16428599-16297369} \\
b & =\frac{66801}{131230}=0,509
\end{aligned}
$$

Menghitung rumus $\alpha$

$$
\begin{aligned}
& \alpha=\frac{\sum y \cdot \sum x^{2}-\sum x \cdot \sum x y}{n \cdot \sum x^{2}-\left(\sum x\right)^{2}} \\
& =\frac{3984 \cdot 169367-4037.166497}{97.169367-(4037)^{2}} \\
& =\frac{674758128-672148389}{16428599-16297369} \\
& =\frac{2609739}{131230} \\
& \alpha=19,8868
\end{aligned}
$$

\section{Persamaan regresi sederhana}

Model regresi yang diperoleh $\mathrm{Y}$ $=19,8868+0,509 \mathrm{X}$.

Artinya konstanta sebesar 19,8868 menyatakan bahwa tanpa Stres kerja, Kinerja karyawan tetap terbentuk sebesar 19,8868.

Variabel Stres kerja berpengaruh positif terhadap kinerja karyawan dengan nilai koefisien sebesar 0,509. Artinya jika variabel Stres kerja meningkat satu satuan, maka Kinerja karyawan akan meningkat sebesar 0,509 .

\section{Uji Signifikan (Uji-t)}

Hasil perhitungan koefisien korelasi perlu diuji untuk mengetahui apakah stress kerja memiliki pengaruh terhadap kinerja karyawan, maka dari itu perlu dilakukan uji signifikan. Dengan melakukan pengujian sebagai berikut:

Ho:p $=0$, tidak terdapat pengaruh yang signifikan antara stress kerja terhadap kinerja karywan PT.PLN (Persero) Area Bintaro
Ho $: p \neq 0$, terdapat pengaruh yang signifikan antara stress kerja terhadap kinerja karyawan PT.PLN (Persero) Area Bintaro

Dengan rumus : $t_{\text {hitung }}=\frac{r \sqrt{n-2}}{\sqrt{1-r^{2}}}$

Thitung $=\frac{0,498 \sqrt{97-2}}{\sqrt{1-0,498^{2}}}$

Thitung $=\frac{0,499 \sqrt{95}}{\sqrt{1-0,248}}$

Thitung $=\frac{0,499.9,74}{\sqrt{0,752}}$

Thitung $=\frac{4,860}{0,867}$

Thitung $=5,606$

Pengambilan

keputusan menggunakan angka perbandingan distribusi ttabel ${ }^{\alpha}=5 \%(0,05)$ dengan derajat kebebasan (df) n-2) dan hasi yang diperoleh untuk ttabel sebesar (97$2=95$ ), dan hasil yang diperoleh untuk ttabel sebesar 1,985 dengan kriteria sebagai berikut:

Jika thitung > ttabel Ho ditolak : Ha diterima (signifikan)

Jika thitung < ttabel Ho diterima : Ha ditolak (tidak signifikan)

Dari hasil analisis diatas dapat diperoleh thitung > ttabel yaitu 5,606>1,985 yang artinya bahwa Ho ditolak Ha diterima, artinya terdapat pengaruh yangsignifikan antara stress kerja terhadap kinerja karyawan pada PT.PLN (Persero) Area Bintaro.

\section{KESIMPULAN DAN SARAN}

\section{A. Kesimpulan}

Dari hasil pembahasan yang telah penulis lakukan maka penulis memberikan beberapa kesimpulan sebagai berikut:

1. Dari hasil penelitian yang telah dilakukan peneliti stress kerja pada karyawan PT.PLN (Persero) Area Bintaro diantaranya yaitu beban kerja yang cukup banyak serta kurangnya adanya apresiasi jenjang karir bagi karaywan yang menimbulakan stress kerja. adapun tanggapan responden 
dengan 10 pernyataan sebanyak 336 atau sebesar $34,63 \%$ dapat dilihat dari jawaban kuisioner.

2. Dari hasil penelitian yang telah dilakukan peneliti kinerja karyawan pada PT.PLN (Persero) Area Bintaro menurun dikarenakan kualitas pekerjaan yang kurang baik dan kemampuan dalam bekerja sama antara karyawan yang kurang baik pula, akan tetapi masih dapat dikendalikan oleh para karyawan. Adapun tanggapan responden dengan 10 pernyataan sebanyak 314 atau sekitar 32,38\% dapat dilihat dari jawaban kuisioner.

3. Terdapat pengaruh yang signifikan antara stress kerja terhadap kinerja karyawan PT.PLN (Persero) Area Bintaro yang dapat dilihat dari nilai uji $\mathrm{t}$ $=5,606$ yang artinya bahwa Ho ditolak, $\mathrm{Ha}$ diterima. besarnya pengaruh (kontribusi) stress kerja terhadap kinerja karyawan sebesar 24,8\%. Tingkat signifikan pengaruh stress kerja terhadap kinerja karyawan PT.PLN (Persero) Area Bintaro katagori sedang yang dapat dilihat dari nilai $r=0,498$ korelasi pearson.

\section{B. Saran}

Untuk mengurangi stress kerja dan meningkatkan kinerja karyawan PT.PLN (Persero) Area Bintaro maka penulis memberikan saran sebagai berikut:

1. PT.PLN (Persero) Area Bintaro hendaknya harus menyeimbangkan beban kerja dengan waktu penyelesaian pekerjaan, dan juga lebih mengapresiasikan pekerjaan karyawan dengan memberikan jenjang karir yang baik bagi karyawan karna karyawan membutuhkan jenjang karir yang lebih baik, sehingga dapat tercapi tujuan, visi, dan misi PT.PLN (Persero) Area Bintaro dan tidak terjadi stress yang menghampiri pada karyawan.

2. PT.PLN (Persero) Area Bintaro disarankan selalu mengadakan evaluasi kinerja setiap perminggu atau perbulan agar kuaitas pekerjaan dan kemampuan kerja sama bisa berjalan dengan baik dan dapat meningkatkan kinerja bagi setiap karyawan.

3. Untuk mengurangi stress kerja para karyawan hendaknya pihak PT.PLN (Persero) Area Bintaro membantu para karaywan untuk memperbaiki kemampuan mereka dalam menghadapi stress dan mengadakan pendidikan serta pelatihan kepada karyawan agar proses pekerjaan berjalan dengan lancer sesuai dengan tujuan perusahaan.

\section{DAFTAR PUSTAKA}

Angipora, Marius. 2012, "Psikologi Dalam Perusahaan”,Aneka Cipta, Jakarta.

Bangun, Wilson. 2012, "Manajemen Sumber Daya Manusia”, Ghalia Indonesia, Jakarta.

Coulter dan Robbin. 2012, "Manajemen Sumber Daya Manusia”. Kencana, Jakarta.

Charles D., Spielberger. 2012

Fahmi, Irham. 2010, "Manajemen Kinerja Teori dan Aplikasi", Penerbit Alfabeta, Bandung.

Handoko, T., Hani. 2009, "Manajemen Personalia \& Sumber Daya Manusia", Penerbit BPFE, Cetakan ke-17, Yogyakarta.

Hasibuan, S.P Malayu. 2010, "Manajemen Dasar, Pengertian dan Masalah”, Edisi Revisi Cetakan Kedelapan, PT Bumi Askara, Jakarta

Mangkunegara, Anwar Prabu. 2013, "Manajemen Sumber Daya Manusia Perusahaan”, Cetakan Ketiga belas, PT Remaja Rosdakarya, Bandung. 